\title{
Validity and Reliability of The Turkish Version of The Solid Waste Management Scale in Health Institutions
}

\section{Sağlık Kurumlarında Katı Atık Yönetimi Öıçeğinin Türkçe Versiyonunun Geçerlik ve Güvenirliği}

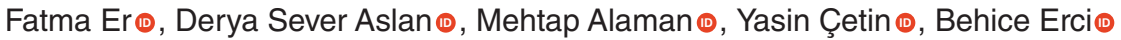

SHYD 2021;8(2):263-272 doi:10.5222/SHYD.2021.92063

Cite as: Er F, Sever Aslan D, Alaman M, Çetin Y, Erci B. Validity and reliability of the turkish version of the solid waste management scale in health institutions. Sağlık ve Hemşirelik Yönetimi Dergisi. 2021;8(2):263-272.

\section{Abstract}

Aim: This research was conducted with the aim to determine the validity and reliability of the Turkish version of the Solid Waste Management Scale in health institutions.

Method: The study population consisted of nurses working in two different hospitals $(918$ $+939=1857$ nurses). The samples were selected from the universe using the improbable sampling method. The data were collected by a Personal Information Form and the Solid Waste Management Scale in Healthcare Institutions. The data were analyzed based on the computations of descriptive statistics including mean, standard deviation, frequencies, percentages, Cronbach's alpha reliability coefficient, Pearson Product Moments Correlation, Factor Analysis, Bartlett's Test, and Kaiser-Meyer-Olkin Test.

Results: The content validity index of the scale was found to be 0.98 . The Cronbach's alpha reliability coefficients of the scale ranged between 0.59 , and 0.73 , while the item factor loads between 0.31 , and 0.94 , and the item-total correlation values between 0.21 , and 0.77 . The factorial structure of the scale was confirmed as a result of the Exploratory and Confirmatory Factor Analyses.

Conclusion: The Turkish version of the Solid Waste Management Scale in Health Institutions showed that it is a valid and reliable tool for determining the level of knowledge and attitudes of nurses working in health institutions about solid waste management. This scale, whose validity and reliability has been tested, can be used to determine the attitudes and knowledge levels of nurses working in health institutions on solid waste management.

Keywords: Validity, reliability, health institutions, solid waste management scale, scale adaptation.

\section{Öz}

Amaç: Bu araştırma, Sağlık Kurumlarında Katı Atık Yönetimi Ölçeği'nin Türkçe versiyonunun geçerlik ve güvenirliğini belirlemek amacıyla yapıldı.

Yöntem: Araştırmanın evrenini, iki ayrı hastanede görevli $(918+939=1857$ hemşire $)$ hemșireler oluşturdu. Araştırmanın örneklemi, olasılıksız örnekleme yöntemi kullanılarak belirlendi $(n=593)$. Araştırmanın verileri, "Kişisel Bilgi Formu ve Sağlık Kurumlarında Katı Atık Yönetimi Ölçeği" kullanılarak toplandı. Verilerin değerlendirilmesinde; Cronbach's alpha güvenirlik katsayısı, Pearson momentler çarpımı korelasyonu, faktör analizi, Barlett testi, Kaiser-Meyer Olkin testi, sayı, yüzde, ortalama ve standart sapma kullanılmıştır

Bulgular: Ölçeğin kapsam geçerlik indeksi 0,98 bulundu. Ölçek faktörlerinin Cronbach's alpha güvenirlik katsayısı 0,59-0,73 arasında, ölçek madde faktör yüklerinin 0,31-0,94 arasında değiştiği ve madde toplam korelasyon katsayılarının 0,21-0,77 arasında olduğu belirlendi. Yapılan açımlayıcı faktör analizi ve doğrulayııı faktör analizi sonucunda ölçeğin üç faktörlü yapısı doğrulandı.

Sonuç: Sağlık Kurumlarında Katı Atık Yönetimi Ölçeği'nin Türkçe formu, sağlık kurumlarında çalışan hemşirelerin katı atık yönetimi konusunda bilgi düzeylerinin ve tutumlarının belirlenmesi için geçerli ve güvenilir bir araç olduğunu gösterdi. Sağlık kurumlarında çalışan hemşirelerin katı atık yönetimi konusundaki tutum ve bilgi düzeylerini belirlemek için geçerlilik ve güvenirliği test edilen bu ölçek kullanılabilir.

Anahtar Sözcükler: Geçerlik, güvenirlik, sağlık kurumları, katı atık yönetimi ölçeği, ölçek uyarlama.
Recieved / Geliş: 23.01.2021

Accepted / Kabul: 04.07.2021

Published Online / Online Yayın: 17.08.2021

Corresponding author / Sorumlu yazar:

Fatma Er

Inonu University, Malatya, Turkey

fatma.er@inonu.edu.tr

ORCID: 0000-0001-8517-9780

D. Sever Aslan 0000-0003-1061-3276 Y. Çetin 0000-0001-5783-5701

Adıyaman University, Adıyaman, Turkey

M. Alaman 0000-0002-9454-7167 Malatya Provincial Health Directorate, Malatya, Turkey

B. Erci 0000-0002-1527-2207 Inonu University, Malatya, Turkey 


\section{The solid waste management scale}

Katı atık yönetimi ölçeği

\section{Introduction}

Hospitals are known as the most important places where healthcare services are provided (İncesu \& Evirgen, 2017). Several and various waste products are formed during processes of diagnosis, treatment and care at both hospitals and other centers that provide healthcare services (Arslan \& Altınkaya, 2007; Birpınar, Bilgili \& Erdoğan, 2009; Doğan \& Göktaş, 2017; Hasçuhadar, Kaya, Şerbetçioğlu, İncesu \& Evirgen 2017; Khan, Cheng, Khan \& Ahmed, 2019; Terzi \& Yüce 2017; Yazie, Tebeje \& Chufa, 2019). The amount and variety of these waste products are constantly increasing due to scientific and technical developments (Incesu \& Evirgen, 2017). The wastes produced in healthcare institutions are defined as domestic wastes, medical wastes, hazardous wastes and radioactive wastes that harm people, especially employees, society and environmental health (Doğan \& Göktaş 2017; Odonkor \& Mahami 2020; Terzi \& Yüce 2017; Tfaily \& Moussa 2020). A good waste management should be planned, implemented and improved to prevent these harmful effects (Assemu, Tafere, Gelaw \& Bantie, 2020; Hasçuhadar et al. 2007; Moreira \& Günther, 2013; Santos, Gonçalves \& Mol, 2019). With good waste management, without harming human health and the environment and all wastes are collected in the most economical way,, separated, turned into usable form, and those that are not converted are safely destroyed (Ertaş \& Güden, 2019; Terzi \& Yüce 2017). It is stated that the planning and implementation of a good waste management system should be followed in accordance with the legislation in force (Ertaş \& Güden, 2019). In a research study, 91.8\% participant nurses, midwives, health officers, dentists, physicians, emergency medical technicians, dental technicians, x-ray technicians, anesthesia technicians and laboratory technicians stated that effective inspections should be made in terms of waste management (İncesu \& Evirgen, 2017).

According to the World Health Organization, one of the most general problems regarding medical wastes is the inadequate management of waste (Terzi \& Yüce 2017). It was reported that success on a desired level cannot be achieved in management of wastes due to lack of sufficient knowledge of healthcare and cleaning personnel in healthcare institutions, lack of their awareness and the insufficiency of economic and human resources allocated for waste management (Doğan \& Göktaş, 2017; Terzi \& Yüce, 2016). Medical waste management is also important for the health of the whole community, especially for the employees of the health institution. For this reason, it is the responsibility of all healthcare personnel, especially nurses, to make waste management properly and sufficiently. According to a literature research in Turkey related to solid waste management in health institutions, few studies have investigated the size and cost of waste disposal methods. However, there are not enough studies conducted to evaluate the attitudes and knowledge levels of nurses regarding the sorting of medical waste. For this reason, it has been necessary to develop a measurement tool to determine the attitudes and knowledge levels of nurses working in health institutions about solid waste management by managers. For this reason, it was necessary to adapt the previously developed measurement tool to Turkish in order to determine the attitudes and knowledge levels of nurses working in health institutions on solid waste management. With this measurement tool, it will be possible to determine the knowledge and attitudes of nurses, who constitute the majority of healthcare professionals and play a primary role in the generation and proper disposal of wastes, in other words management of medical waste. By adapting this instrument into Turkish, the sensitivities of nurses on solid waste management will be evaluated, the correct attitudes and behaviors will be supported by raising awareness through in-service trainings when needed, or behaviors that will improve these attitudes will be achieved. Evidence-based data will also be obtained for taking strategic precautions that may reduce the financial costs of hospitals by usage of the scale in a broader scope.

\section{Method}

Aim of the Study: This study aimed to determine the validity and reliability of the "Solid Waste Management Scale" in healthcare institutions in Turkish.

Research Question: Based on this research, answers to the following question were sought: "Is the Turkish version of the "Solid Waste Management Scale" in health institutions valid and reliable?"

Type of the Study: This is a methodological study for determining the validity and reliability of the "Solid Waste Management Scale" for Turkish nurses in healthcare institutions.

Location and Time of the Study: The study was carried out at X Hospital and XX Hospital between May 1, 2019 and August 1, 2019. In order to keep the population and sample size and to ensure diversity, two hospitals belonging to different institutions in the province where the study was conducted were included in the scope of the study. Hospital $X$ is the University hospital. Hospital XX is affiliated with the Ministry of Health. X hospital has 1368, and XX hospital has 1040 beds.

Population and Sample: The study population included all nurses employed at $X(N=918)$ and $X X(N=939)$. In forming the research sample; the sample size was determined using power analysis to be at least 593 nurses with a $5 \%$ error, $95 \%$ confidence interval and 0.5 effect size according to the two-sided significance level $(n=593)$. The sample was selected from the universe using the improbable sampling method. There were no inclusion and exclusion criteria of the study. 
Data Collection Instruments: Personal Information Form and the Solid Waste Management Scale in Healthcare Institutions were the instruments used for data collection.

Personal Information Form: This form inquires participants' age, gender, educational status, etc., and consists of 18 questions.

Solid Waste Management Scale in Healthcare Institutions: The scale was developed in 2016 by Ali, Wang and Chaudhry. The original scale contains 10 items and 3 dimensions as the Reputation Dimension, Liability Dimension and Expense Dimension (Ali, Wang \& Chaudhry 2016). Reputation dimension consists of 4 items such as: "I don't mind paying to receive trainings and education on Hospital Waste Management" etc. Liability dimension consists of 3 items such as:, "There is pressure from regulatory authorities for HWM" etc. Expense dimension consists of 3 items such as:, "Adoption of improved HWM will create extra burden on the existing staff at our facility"etc.. For each item the scores ranged from 1 and 5 (1-Absolutely disagree 2-Disagree, 3-No idea, 4-Agree and 5-Absolutely agree). The Reputation Dimension (Items 1,2,3,4) with a score range of 1-20, the Liability Dimension (Items 5,6,7) with a score range of 1-15 and the Expense Dimension (Items $8,9,10$ ) with a score range of $1-15$ constitute a total score range of 1-50 for the whole scale. Cronbach's alpha was not calculated for the original scale. For the original scale, after completion of the exploratory factor analysis, the Confirmatory Factor Analysis (CFA) was performed to enhance the quality of findings on the scale's dimensions. The CFA fit index values on the original scale were reported as: $X^{2}=19.28$., $d f=20(p>0.05), X^{2} / d f=1.314, R M S E A=0.033, G F I$ : 0.96 CFI: 0.98. (Ali, Wang \& Chaudhry 2016).

Data Collection: The Solid Waste Management Scale in Healthcare Institutions was culturally adapted following a certain process with three stages: linguistic validity, content validity and pilot scheme.

In the language translation of the Solid Waste Management Scale in Health Institutions, the scale was translated from English to Turkish by three researchers. The scale questions translated into Turkish were translated back to a British linguist who knows both languages. Scale translation was re-examined by an expert linguist, and the original scale was compared with the Turkish version of the scale. Required comparisons were made, and it was determined that there was no meaning change in the items of the scale and the language validity of the scale was completed.

For content validity test to identify the comprehensibility of the scale items in Turkish, the scale forms in English (original) and Turkish were e-mailed to five faculty members having expertise, two in Public Health Nursing, one in Management in Nursing, one in Fundamentals of Nursing, and one in Obstetrics and Gynecology Nursing, as well as an expert nurse. These academicians and professionals were asked to score each item from 1 to 4 (1-not suitable, 2-somehow suitable, 3-highly suitable4-very suitable) and asked to make assessment on the expediency and comprehensibility of the scale. In this study, the content validity index was found as 0.98 ( $\mathrm{CVI}>0.98)$. CVI values of higher than 0.80 are desired. Therefore, the content validity of the scale was achieved (Content validity 3.9 ).

The professional judgments were followed to organize a pilot scheme with 30 nurses. The pilot-scheme outcomes were not added into the sample. Consequently, it was realized that the scale items were comprehensible. Thus, the Turkish adaptation of the Solid Waste Management Scale in Healthcare Institutions was finalized.

The data were collected from the forms distributed to and completed by the participant nurses in the hospital environment. The questionnaire forms were distributed to the nurses by the researchers. After the nurses filled out the forms, they were collected by the researchers. It took a nurse no more than fifteen minutes to complete the forms.

Validity: Factor analysis was exercised to identify the construct validity of the scale. Priorly, Kaiser-Meyer-Olkin Measure of Sampling Adequacy (KMO) and Bartlett's Test of Sphericity were applied to measure sample adequacy and testing ability, respectively. Suitability for factor analysis was judged when the KMO coefficient of the sample size adequacy was higher than 0.50. Higher KMO values indicate higher suitability (Kalaycl 2010). Bartlett's Test determines the association between the variables based on partial correlations (Büyüköztürk 2010; Yong and Pearce 2013). For this, Bartlett's Test of Sphericity should produce a statistically significant result (Kalaycı 2010). For factor structure analysis of the scale, the Principal Component Analysis was used, which is one of the most common methods in statistics. It was reported that the factor load of 0.30 or 0.40 could be used as cut- off value to form the factor pattern (Büyüköztürk 2010). In this study the lower limit was established as 0.30 for factor loads.

Followed by the exploratory factor analysis, Confirmatory Factor Analysis (CFA) was conducted to enhance the quality of the scale's dimensions. The fitness conditions for model are accepted as the ratio of $X^{2} / \mathrm{df}(\leq 5)$, the RMSEA value $(\leq 0.08)$, and the CFI and IFI values (>0.90) (Erkorkmaz et al. 2013).

Reliability: The reliability of Likert-type scale is measured through calculation of the internal consistency coefficient of 


\section{The solid waste management scale}

Katı atık yönetimi ölçeği

Cronbach's alpha. The coefficient takes a value between 0 and 1, where values closer to 1 are more acceptable (Kalaycl 2010). Item-total correlation coefficients measure the relationship between the item scores and the total score of the scale. High and positive item-total correlation values indicate that the scale questions represent similar behaviors, and the test shows high internal consistency (Büyüköztürk 2010). It is reported that the items whose item-total correlation coefficient is lower than 0.20 should be excluded from the scale prior to the test (Büyüköztürk 2010). This limit was also accepted in this study.

Data Analysis: Statistical analysis was conducted on the software programs of SPSS25.0 and AMOS 22.0.The data were analyzed based on the computations of descriptive statistics including mean, standard deviation, frequencies, and percentages and of Cronbach's alpha reliability coefficient, Pearson Product Moments Correlation, Factor Analysis, Bartlett's Test, and Kaiser-Meyer-Olkin Test.

Ethical Considerations: Written approval was obtained for the study from the Ethics Board of XXX Health Sciences NonInterventional Clinical Studies and the Ethics Committee on Scientific Research and Publication (Decision Number: 2019/63). For the scale used in the study, permission was obtained via e-mail from those who developed the scale. Permissions were also obtained from the managements of the $X$ and $X X$ Hospitals for the study to be carried out. The principle of "respect for human dignity" was complied with by informing the participants on the objective and plan of the study and where the data would be used, the "respect for autonomy" principle was complied with by including those who volunteered, and the principle of "privacy and protection of privacy" was complied with by ensuring the participants that the data obtained from the study would be kept confidential.

\section{Results}

The results of the study were presented in this section. Table 1 shows the descriptive and occupational characteristics of the participants.

Table 1. Distribution of the descriptive and occupational characteristics of the participants (N: 593)

\begin{tabular}{|c|c|c|}
\hline Descriptive and Occupational Characteristics $(\mathrm{N}=593)$ & $\mathbf{n}$ & $\%$ \\
\hline \multicolumn{3}{|l|}{ Gender } \\
\hline Female & 502 & 84.7 \\
\hline Male & 91 & 15.3 \\
\hline \multicolumn{3}{|l|}{ Education Level } \\
\hline High School & 29 & 4.9 \\
\hline University & 486 & 82.5 \\
\hline Master's & 66 & 11.2 \\
\hline $\mathrm{PhD}$ & 8 & 1.4 \\
\hline \multicolumn{3}{|l|}{ Institution of Employment } \\
\hline Malatya Research and Training Hospital & 282 & \multirow{2}{*}{$\begin{array}{l}47.6 \\
52.4\end{array}$} \\
\hline Turgut Özal Medical Center & 311 & \\
\hline \multicolumn{3}{|l|}{ Position } \\
\hline Care Nurse & 366 & 61.7 \\
\hline Intensive Care Nurse & 139 & 23.4 \\
\hline Service Supervisor Nurse & 28 & 4.7 \\
\hline Nurse manager other than Service Supervisor Nurse & 5 & 8.0 \\
\hline Other (nurses working at other departments other than care nurses) & 55 & 9.3 \\
\hline \multicolumn{3}{|l|}{ Economic Status } \\
\hline Good & 109 & 18.6 \\
\hline Moderate & 408 & 69.5 \\
\hline \multirow[t]{2}{*}{ Bad } & 70 & 11.9 \\
\hline & $\mathrm{X} \pm \mathrm{SD}$ & \\
\hline Age & $35.61 \pm 6.97$ & \\
\hline Years of Service & $13.60 \pm 8.09$ & \\
\hline
\end{tabular}

In this study, $84.7 \%$ of the participants were female, $82.5 \%$ had undergraduate degrees, $61.7 \%$ were working as care nurse, and $69.5 \%$ had a moderate economic status. Mean age of the participants was $35.61 \pm 6.97$, and their mean duration of employment was $13.60 \pm 8.09$ years. 
Table 2. Distribution of variables regarding the attitudes and knowledge levels of nurses on Solid Waste Management (N: 593)

\begin{tabular}{|c|c|c|}
\hline Attitude and Knowledge Level on Solid Waste Management & $\mathbf{n}$ & $\%$ \\
\hline \multicolumn{3}{|l|}{ Status of Having Received Training on Solid Wastes } \\
\hline Yes & 437 & 73.9 \\
\hline No & 147 & 24.9 \\
\hline Do not remember & 7 & 1.2 \\
\hline \multicolumn{3}{|c|}{$\begin{array}{l}\text { Status of Caring about the Job of Sorting Solid Wastes at the Source in Healthcare } \\
\text { Institutions }\end{array}$} \\
\hline Yes & 539 & 91.0 \\
\hline No & 5 & 0.8 \\
\hline Partly & 38 & 6.4 \\
\hline No idea & 10 & 1.7 \\
\hline \multicolumn{3}{|l|}{ Should Regular In-Service Trainings on Waste Be Provided? } \\
\hline Yes & 242 & 85.8 \\
\hline No & 8 & 2.8 \\
\hline Partly & 23 & 8.2 \\
\hline No idea & 9 & 3.2 \\
\hline \multicolumn{3}{|l|}{ Status of Thinking One Has Sufficient Knowledge on Solid Wastes } \\
\hline Yes & 170 & 28.7 \\
\hline No & 96 & 16.2 \\
\hline Partly & 308 & 51.9 \\
\hline No idea & 19 & 3.2 \\
\hline \multicolumn{3}{|l|}{ Should There Be More Effective Inspection on Waste Management? } \\
\hline Yes & 471 & 79.6 \\
\hline No & 23 & 3.9 \\
\hline Partly & 77 & 13.0 \\
\hline No idea & 21 & 3.5 \\
\hline
\end{tabular}

Status of Instruction on Directive for Solid Waste Management at Department of

Employment

Yes

No

Partly

No Idea

Status of Thinking Legal Regulations on Solid Waste Management Are Sufficient Yes

No

Partly

No idea

The Most Important Problem Experienced by Nurses regarding Solid Wastes No problem

All is mixed while collecting wastes

Nurses are not careful enough

Nurses are held liable for mistakes of others while separating wastes

Wastes are carried on the same elevator used by the patients

There are sharp and penetrating objects 


\section{The solid waste management scale}

Katı atık yönetimi ölçeği

Table 2 shows the distribution of variables on the behaviors of the nurses towards solid waste management. Most (73.9\%) of the participants received training regarding solid wastes, $91 \%$ cared for the job of sorting solid wastes at their source in healthcare institutions, $85.8 \%$ stated that regular in-service trainings should be provided about wastes. $51.9 \%$ of the participants thought that they had partly sufficient knowledge on solid wastes, $79.6 \%$ stated the need for more effective inspection in terms of solid waste management, $58.7 \%$ said that there were instructions on the directive for solid wastes at the department of their work, and $37.9 \%$ stated that the legal regulations on solid waste management are partly sufficient. $20.7 \%$ said that lack of training was the most important problem they experienced regarding management of solid wastes.

\section{Content Validity}

For content validity test to identify the comprehensibility of the scale items in Turkish, the scale forms in English (original) and Turkish were e-mailed to five faculty members having expertise, two in Public Health Nursing, one in Management in Nursing, one in Fundamentals of Nursing, and one in Obstetrics and Gynecology Nursing, as well as an expert nurse. These academicians and professionals were asked to score each item from 1 to 4 (1-not suitable, 2-somehow suitable, 3-highly suitable, and 4-very suitable) and to evaluate the expediency and comprehensibility of the scale. The expert panel reviewed the Turkish scale with 10 items and decided on the relevance and phrasing structure. For each item, the experts suggested several modifications in the phrases of the items. Subsequently, the scale was revised multiple times followed by rediscussions until consensus was reached among the Panel members on the content. In this study, the content validity index was found as $0.98(\mathrm{CVI}>0.98)$. CVI values of higher than 0.80 are desired. Therefore, the content validity of the scale was achieved (Content validity 3.9 ).

\section{Construct Validity}

$\mathrm{KMO}$ and Barlett's test were used to identify the sample size prior to factor analysis. Priorly, Kaiser-Meyer-Olkin Measure of Sampling Adequacy (KMO) and Bartlett's Test of Sphericity were applied to measure sample adequacy and testing ability, respectively. In the present study, the KMO value was calculated as 0.682 , and the Bartlett's test of sphericity was found to yield significant results $(p=0.000)$. Accordingly, it was judged that the number of samples was sufficient and suitable for factor analysis. Factor analysis was exercised to identify the construct validity of the scale.

Table 3. Principal component analysis followed by varimax rotation, factor loadings and item-total correlations of items of the scale

\begin{tabular}{|c|c|c|c|c|c|c|}
\hline \multirow[b]{2}{*}{ Item } & \multicolumn{3}{|c|}{ Item of factor loading } & \multirow{2}{*}{$\begin{array}{l}\text { Item-Total } \\
\text { Correlation }\end{array}$} & \multirow{2}{*}{$\begin{array}{l}\text { Cronbach's } \\
\text { alpha }\end{array}$} & \multirow[t]{2}{*}{ Variance } \\
\hline & Factor I & Factor II & Factorlll & & & \\
\hline Reputation Indicators & & & & 0.77 & 0.64 & 24.6 \\
\hline $\begin{array}{l}\text { I don't mind paying to receive trainings and education on } \\
\text { Hospital Waste Management }\end{array}$ & .944 & & & .450 & .731 & \\
\hline $\begin{array}{l}\text { It is important that patients perceive our health facility } \\
\text { as clean }\end{array}$ & .796 & & & .535 & .599 & \\
\hline Government regulation should be followed for HWM & .766 & & & .525 & .609 & \\
\hline $\begin{array}{l}\text { A cleaner facility helps boost the morale of the staff at } \\
\text { a facility }\end{array}$ & .778 & & & .536 & .604 & \\
\hline Liability Indicators & & & & 0.59 & 0.59 & 19.2 \\
\hline There is pressure from regulatory authorities for HWM & & .317 & & .209 & .667 & \\
\hline $\begin{array}{l}\text { The municipality can close our facility for non-complian- } \\
\text { ce with regulations }\end{array}$ & & .770 & & .302 & .652 & \\
\hline Our facility might be sued for poor HWM & & .784 & & .338 & .645 & \\
\hline Expense Indicators & & & & 0.64 & 0.70 & 16.6 \\
\hline $\begin{array}{l}\text { Adoption of improved HWM will create extra burden on } \\
\text { the existing staff at our facility }\end{array}$ & & & .593 & .333 & .646 & \\
\hline $\begin{array}{l}\text { The adoption and implementation of sound HWM practi- } \\
\text { ces will be a financial burden for our facility }\end{array}$ & & & .775 & .311 & .650 & \\
\hline $\begin{array}{l}\text { It is difficult to adopt better health-care waste manage- } \\
\text { ment practices due to a lack of funds }\end{array}$ & & & .570 & .391 & .634 & \\
\hline Total & & & & & 0.68 & 60.4 \\
\hline
\end{tabular}

For factor structure of the scale, the Principal Component Analysis was used, which is one of the most common methods in statistics. A principal component analysis was the first stage in the analysis. The number of factors were found when 
estimated eigenvalues were greater than one $(>1)$. The analysis revealed three factors with an appropriate eigenvalue (Table 3). The combination of three factors accounted for $60.4 \%$ of the variance. The factor of "Reputation Indicators" with the factor loads ranged from .76 to .94 , and accounted for $24.6 \%$ of the total variance, "Liability Indicators" with the factor loads from .31 to .78 accounted for $19.2 \%$, and "Expense Indicators" with the factor loads from .57 to .77 accounted for $19.2 \%$ of the total variance. The factor loads of the items varied between 0.20 and 0.70 . In this study the lower limit was established as 0.30 for factor loads.

Table 4. Goodness of fit indices for confirmatory factor analysis of the solid waste management scale in healthcare institutions

\begin{tabular}{lcccccc} 
& $\mathbf{X}^{2}$ & df & $\mathbf{X}^{2} / \mathbf{d f}$ & RMSEA & CFI & IFI \\
\hline SWMSHI & 96.802 & 28 & 3.457 & 0.064 & 0.95 & 0.95
\end{tabular}

Followed by the exploratory factor analysis, Confirmatory Factor Analysis (CFA) was conducted to enhance the quality of the scale's dimensions. The fitness conditions for model were accepted as the ratio ofX2/df( $\leq 5)$, the RMSEA value ( $\leq 0.08)$, and the CFI and IFI values (>0.90) (Erkorkmaz et al. 2013). For the scale the goodness-of-fit indices were found as: $X^{2}=147.339$, $d f=32(p<0.05), X^{2} / d f=4.60, R M S E A=0.078$. The RMSEA and $X^{2} / d f$ values did not show a good fit. According to modification recommendations, there were high error covariances in 5-6, 5-7; 8-9, and 8-10 items. A second CFA was applied on these items in relation to the error covariances. As a result of this CFA, the following values were found: $X^{2}=96.802, d f=28(p<0.05)$, $X^{2} / \mathrm{df}=3.457, \mathrm{RMSEA}=0.064, \mathrm{IFI}=0.95$ and $\mathrm{CFI}=0.95$ (Table 4). The associated path diagram is shown in Figure 1.

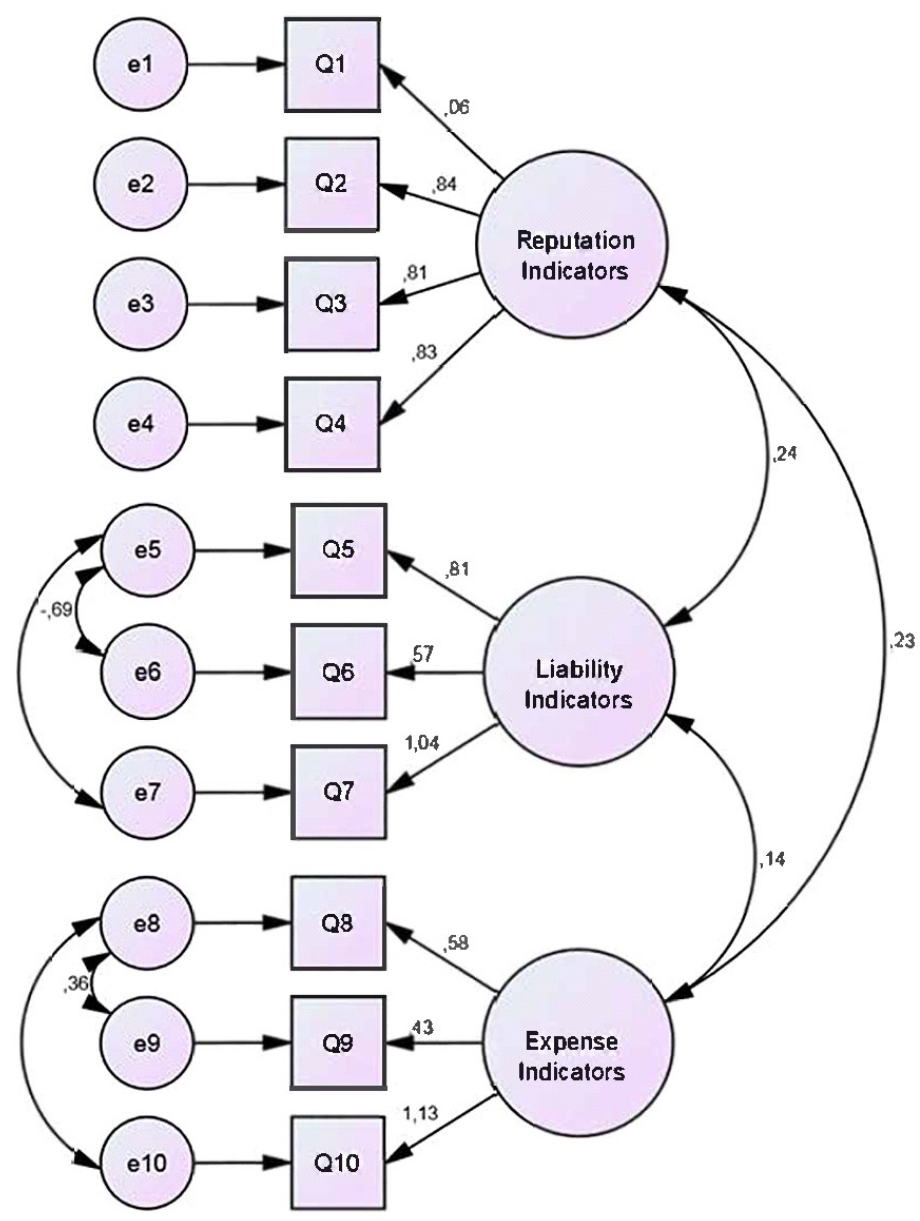

Figure 1. Model of the factor structure of the solid waste management scale in healthcare institutions 


\section{The solid waste management scale}

Katı atık yönetimi ölçeği

The total score average of the Solid Waste Management Scale in Health Institutions was determined as $31.18 \pm 5.31$. The mean $( \pm$ SD) scores for the factors were determined as follows: Reputation Indicators:14.32 \pm 3.15 ; Liability Indicators": 8.54 \pm 2.04 , and Expense Indicators: $8.31 \pm 2.48$.

\section{Reliability}

Five hundred and ninety-three nurses participated in the research , and completed all forms. The overall coefficient $\alpha$ was computed as 0.68 for the Solid Waste Management scale. The $\alpha$ values of the subdimensions remained within a range of 0.59 to 0.70 (Table 3). The alfa coefficient takes a value between 0 and 1 , where values closer to 1 are more acceptable. Item-total correlation coefficients measure the relationship between the item scores and the total score of the scale. This limit was also accepted in this study. Further, the limits were 0.18 and 0.53 for the calculated item-total correlations (Table 3) which indicated a non unidimensional scale.

\section{Discussion}

This study adapted the Solid Waste Management Scale in healthcare institutions developed by Ali, Wang and Chaudhry (2016) into Turkish. Followed by its assessment by a sample of Turkish nurses. it was determined that the validity and reliability of the scale were satisfied as an instrument to evaluate solid waste management in healthcare institutions.

Content Validity: For content validity test to identify the comprehensibility of the scale items in Turkish, the scale forms in English (original) and Turkish were e-mailed to five faculty members having expertise, two in Public Health Nursing, one in Management in Nursing, one in Fundamentals of Nursing, and one in Obstetrics and Gynecology Nursing, as well as an expert nurse. In this study, the content validity index was found as 0.98 (CVI>0.98). CVI values of higher than 0.80 are desired. Therefore, the content validity of the scale was achieved (Content validity 3.9).

Construct Validity: Exploratory Factor Analysis (EFA) and Confirmatory Factor Analysis (CFA) were utilized to decide on the construct validity of the scale.

The principal component analysis with varimax rotation demonstrated that three factors were distinguished in terms of content as indicators about reputation, liability and expense. (Kalaycı 2010). The original scale contained dimensions of reputation, liability and expense. Our study results were consistent with those reported by Ali, Wang and Chaudhry.

In this study, three dimensions totally accounted for $60.4 \%$ of the variance based on a well grounded explanation. In the study of Ali, Wang and Chaudhry (2016) this rate was estimated as 63\%. Besides, it has been reported that the explained variance should be $30 \% \geq$ (Erefe, 2011; Kimberlin and Winterstein, 2008).

Based on the principal component analysis conducted, the factor loadings of the scale items ranged from 0.31 to 0.94 , which was above 0.30. Ali, Wang and Chaudhry (2016) also reported that these factor loadings were above 0.30 for the original scale. In other words, the critical level of factor loading was satisfied in the present study (Büyüköztürk 2010).

All items had higher factor loadings than the threshold. Accordingly, the Solid Waste Management scale met the criteria of construct validity based on the statistical analyses. (Table 3).

Followed by the exploratory factor analysis, Confirmatory Factor Analysis (CFA) was conducted to enhance the quality of findings related to the scale's dimensions. Quantitatively, the CFA fit index values were computed as: $X^{2}=147.339, \mathrm{df}=32$ $(p<0.05), X^{2} / d f=4.60$, RMSEA=0.078. According to the statistics, the RMSEA and $X^{2} / d f$ values showed that the model fitness was poor. With respect to modification recommendations, error covariances were higher in items 5-6, 5-7; 8-9, and 8-10. A second CFA was applied on these items in relation to the error covariances. As a result of this CFA, the following values were found: $X^{2}=96.802, d f=28(p<0.05), X^{2} / d f=3.457, R M S E A=0.064, I F I=0.95$ and $C F I=0.95$ (Table 4).

For the original scale, after completion of the exploratory factor analysis, the Confirmatory Factor Analysis (CFA) was performed to enhance the quality of findings on the scale's dimensions (Ali, Wang and Chaudhry 2016). The CFA fit index values on the original scale were reported as: $X^{2}=19.28$., $d f=20(p>0.05), X^{2} / d f=1.314, R M S E A=0.033, G F I: 0.96$ CFI: 0.98 .

The confirmatory factor analysis made adjusted three dimensions in our study. According to the achieved results, the solid waste management scale satisfied the criteria of construct validity for Turkish nurses.

Reliability: Reliability of a tool measurement is important for accuracy of measurements Therefore, the Cronbach's alpha analysis was conducted to quantify the reliability of the scale. The Cronbach's alpha coefficients were computed as 0.68 for 
the total scale, 0.64 for reputation, 0.59 for liability, and 0.70 for the expense. (Table 3 ). The Cronbach's alpha coefficients may take values only between 0 and 1. For scale quality, the values should become closer to 1.The instrument shows no reliability for smaller values than 0.40 , low reliability for values varying from 0.40 to 0.59 , moderately high reliability for values from 0.60 to 0.79 , and very high reliability for values from 0.80 to 100 (Kalaycı 2010). Higher Cronbach's alpha coefficients of the scale, indicate that the items of the scale are consistent with each other, examine the elements of the same feature, or that all items work together to the same extent (Kalaycı 2010). The Solid Waste Management Scale was observed to be moderately reliable. The Cronbach's alpha reliability coefficient had remained unchecked in previous studies for the validity and reliability of the original scale (Ali, Wang \& Chaudhry 2016). Each inter-item correlation had acceptable range of 0.20 to 0.77 , and the scale seemed to be adequately homogeneous (Table 3 ). The original scale in English did not emphasize each inter-item correlation (Ali, Wang \& Chaudhry 2016).

The lowest acceptable level for individual inter-item correlation coefficient has been determined as 0.15 in various studies (DeVellis, 2012; Yang and Green, 2011). In the current study the critical point was 0.20 above that threshold value . As the correlation coefficient for each item of a scale increases, its effectiveness and measurement quality for the behaviors of study participants also increases. When item-total correlation coefficent is highly positive, the test shows high internal consistency within the scale, and the items reflect the common behaviors (Büyüköztürk 2010). The present study exhibited the efficient psychometric characteristics of the Turkish adaptation of the Solid Waste Management Scale in Health Institutions and it was determined that the original scale was consistent with the English study.

\section{Conclusion and Recommendations}

Turkish adaptation of the Solid Waste Management Scale in Healthcare Institutions showed consistent results with the original scale in English. Our findings revealed that this scale provides valid and reliable measurement to assess the knowledge and attitudes of nurses on solid waste management. Conduction of studies in different sample groups using this scale can be recommended.

Implications for Practice: The Solid Waste Management Scale, which has been tested for validity and reliability, may be used to determine the attitudes and knowledge levels of nurses working at healthcare institutions on solid waste management. By using the scale in a broader scope, the financial costs of hospitals may be reduced, and it may be possible to obtain evidence-based data for strategic precautions to be taken. Quality may be increased with a well-managed solid waste management in healthcare institutions.

Implications for nursing management: It was determined that the Solid Waste Management Scale in Health Institutions adapted to Turkish, is a valid and reliable tool for determining nurses' attitudes and knowledge levels on solid waste management.

Ethics Committee Approval was obtained from The Ethics Committee of Health Sciences Non-Interventional Clinical Studies and the Ethics Committee on Scientific Research and Publication (Decision Number: 2019/6-3).

Conflict of Interest: Not reported.

Funding: None.

Informed Consent: Written informed consents of the participants were obtained.

\section{References}

Ali, M., Wang, W. \& Chaudhry, N. (2016). Investigating motivating factors for sound hospital waste management. Journal of The Air\&Waste Management Association, 66(8), 786-794. https://doi.org/10.1080/10962247.2016.1181686

Assemu, D., Tafere, T., Gelaw, Y. \& Bantie, G. (2020). Healthcare waste management practice and associated factors among private and public hospitals of Bahir Dar city administration. Journal of Environmental and Public Health, 1-10. https://doi.org/10.1155/2020/7837564

Birpınar, M. E., Bilgili, M. S. \& Erdoğan, T. (2009). Medical waste management in Turkey: A case study of Istanbul. Waste Management, 29, 445-448. https://doi.org/10.1016/j.wasman.2008.03.015

Büyüköztürk, Ş. (2010). Sosyal bilimler için veri analizi el kitabı. Ankara, Türkiye: Pegem Akademi Yayınevi, 12. Baskı. 124, $126,171$.

DeVellis, R. F. (2012). Scale development theory and applications (3rd ed.). University of North Carolina.

Doğan, P. \& Göktaş, S. (2017). Hemşirelik öğrencilerinin hastane atıklarının yönetimine ilişkin bilgi düzeyleri. Kocatepe Tıp Dergisi, 15, 9499. https://doi.org/10.18229/kocatepetip.344668

Erefe, I. (2011). Features of data tools. In I. Erefe (Ed.), Research in nursing (pp. 169-199). Odak Ofset. 
Erkorkmaz, Ü., Etikan, İ., Demir, O., Özdamar, K. \& Sanisoğlu, Y. S. (2013). Doğrulayıcı faktör analizi ve uyum indeksleri. Turkiye Klinikleri Journal of Medical Sciences,, 33(1), 210-223. https://doi.org/10.5336/medsci.2011-26747

Ertaş, H. \& Güden, M. A. (2019). Hastanelerde tıbbi atık yönetimi. Sosyal Araştırmalar ve Yönetim Dergisi, 1, 53-67. https://doi.org/10.35375/sayod.541876

Hasçuhadar, M., Kaya, Z., Şerbetçioğlu, S., Arslan, T. \& Altınkaya, S. (2007). Ankara Atatürk Eğitim ve Araştırma Hastanesi personelinin tıbbi atık konusunda bilgi düzeyi. Turkish Medical Journal, 1, 138-144.

İncesu, E. \& Evirgen, H. (2017). Sağlık çalışanlarının hastane atıkları konusunda bilgi düzeylerinin değerlendirilmesi ve atık minimizasyonu: Konya Kamu Hastaneleri Birliği Genel Sekreterliği Örneği. Gümüşhane Üniversitesi Sağlık Bilimleri Dergisi, 6(3), 56-64.

Kalaycı, Ş. (2010). SPSS uygulamalı çok değişkenli istatistik teknikleri. Editör. Şeref Kalaycı. 5. Baskı, Asil yayın Dağıım, Ankara. $321-331$.

Khan, B., Cheng, L., Khan, A. \& Ahmed, H. (2019). Healthcare waste management in asian developing countries: A mini review. Waste Management \& Research, 37(9), 863-875. https://doi.org/10.1177/0734242X19857470.

Kimberlin, C. L. \& Winterstein, A. G. (2008). Validity and reliability of measurement instruments used in research. American Journal Health System Pharmacia, 65(23), 2276-2284. https://doi.org/10.2146/ ajhp070364.

Moreira, A. M. M. \& Günther, W. M. R. (2013). Assesment of medical waste management at a primary health-care center in São Paulo, Brazil. Waste Management, 33, 162- 167. https://doi.org//10.1016/j.wasman.2012.09.018

Odonkor, S. \& Mahami, T. (2020) Healthcare waste management in Ghanaian hospitals: Associated public health and environmental challenges. Waste Management \& Research, 38(8), 831-839. https://doi.org/10.1177/0734242X20914748

Santos, E., Gonçalves, K. \& Mol, M. (2019). Healthcare waste management in a Brazilian university public hospital. Waste Management \& Research, 37(3), 278-286. https://doi.org/10.1177/0734242X18815949

Terzi, Ö. \& Yüce, M. (2017). Bir hastanedeki stajyer öğrencilerin tıbbi atık yönetimi konusundaki bilgi düzeylerinin değerlendirilmesi. Gümüşhane Üniversitesi Sağlık Bilimleri Dergisi, 6(1), 58-64.

Tfaily, M. \& Moussa, S. (2020). Assessment of healthcare waste management in hospitals of South Lebanon. BAU Journal - Health And Wellbeing, 2(2), 1-12.

Yang, Y. \& Green, S. B. (2011). Coefficient alpha: A reliability coefficient for the 21st century? Journal of PsychoEeducational Assessment, 29(4), 377-392. https://doi.org/10.1177/0734282911406668.

Yazie, T., Tebeje, M. \& Chufa, K. (2019). Healthcare waste management current status and potential challenges in Ethiopia: A systematic review. BMC Research Notes, 12(285), 1-7. https://doi.org/10.1186/s13104-019-4316-y

Yong, A. G. \& Pearce, S. (2013). Beginner's guide to factor analysis: Focusing on exploratory factor analysis. Tutorials in Quantitative Methods for Psychology, 9(2), 79-94. https://doi.org/10.20982/tqmp.09.2.p079 